\title{
Conservation management rules for reconstructing Moluccan Scrubfowl (Eulipoa wallacei) egg-laying habitats
}

\section{Halvina Grasela SAIYA ${ }^{1 *}$ \& Cornelis Johannes HeIJ ${ }^{2}$}

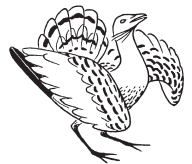

Saiya, H. G. \& Heij, C. J. 2021. Conservation management rules for reconstructing Moluccan Scrubfowl (Eulipoa wallacei) egg-laying habitats. - Ornis Hungarica 29(1): 47-65. DOI: 10.2478/orhu-2021-0004

\begin{abstract}
This research focused on the efforts of indigenous people invested into the reconstruction of damaged Moluccan Scrubfowl (Eulipoa wallacei) egg-laying habitats, as well as, on the ways how the current conditions of the landscapes are conserved by indigenous people. This is a qualitative and quantitative study that used a combination of observation and interview methods. We also used descriptive analysis and spatial analysis including remote sensing techniques. The results showed that the abrasion process that destroyed the Moluccan Scrubfowl egg-laying habitat left a remaining sandbar with an area of $1,161 \mathrm{~m}^{2}$, or about $17 \%$ of the area of the initial sandbar. Even though the habitat has not fully recovered, Moluccan Scrubfowls still lay their eggs there. The details of the reconstruction activities carried out by indigenous people are as follows: making embankments, adding sand to the eroded area, replanting supporting coastal vegetation, and making breeding sites. In addition, efforts were also made to restore the surrounding support areas that were also damaged. The activities carried out were as follows: replantation of coral reefs, turtle breeding, nurseries and mangrove planting, nurseries of other plant species such as cloves and nutmegs, picking up trash along the coast, and early education for children in how to be environmentally conscious.
\end{abstract}

Keywords: Moluccan Scrubfowl, degradation, habitat, abrasion, conservation, indigenous people

Összefoglalás A jelen vizsgálat a helyi lakosok a maluku-szigeteki ásótyúk (Eulipoa wallacei) rongálódott tojásrakó helyeinek rekonstrukciója érdekében tett erőfeszítéseivel foglalkozik, valamint azzal, hogy a tájkép jelen állapotát hogyan védelmezik ezek a törzsek. Ezen tanulmány mind kvalitatív, mind kvantitatív megközelítéseket alkalmaz, kombinálva a megfigyeléses és interjúztató adatgyüjtést. Emellett leíró statisztikai értékelést, valamint távérzékelési eljárásokat magában foglaló térbeli elemzéseket is végeztünk. Eredményeink alapján a vizsgált faj tojásrakó élőhelyeit tönkretevő abráziós folyamat egy $1,161 \mathrm{~m}^{2}$ kiterjedésủ homokbuckát hagyott csak érintetlenül, ami az eredeti élőhelynek 17\%-a. Bár az élőhely még nem állt helyre, az ásótyúkok továbbra is raknak itt tojást. A helyi bennszülöttek a következő élőhelyrekonstrukciós tevékenységeket végezték: gátépítés, homokráhordás, a homokszerkezetet stabilizáló parti növényzet újratelepítése, és fészkelő helyek készítése. Ezen felül a környező, stabilitást adó, de rongálódott élőhelyek rekonstrukciójára is sor került: korallzátonyok újratelepítése, tengeri teknösök szaporítása, teknősnevelés és mangrove-ültetés, mirtuszfélék és szerecsendió ültetése, szemétszedés a parton, és környezeti nevelés.

Kulcsszavak: maluku-szigeteki ásótyúk, degradáció, élőhely, abrázió, természetvédelem, helyi lakosok

\footnotetext{
${ }^{1}$ School of Environmental Science, Universitas Indonesia, Jakarta, Indonesia

${ }^{2}$ Natural History Museum, Rotterdam, The Netherland

"corresponding author, e-mail: halvina.grasela@ui.ac.id
} 


\section{Introduction}

"Conservation" is a term that refers to the acts of protecting, preserving, and sustainably using natural resources. Furthermore, conservation is a form of natural resource allocation that is carried out optimally across different generations (Randall 1981, 2007), which relates to the principle that natural resources must remain available to future generations. In other words, the current generation does not have the full right to control or use all available natural resources because those must be left for future generations. Conservation also involves the management of the biosphere, which takes into account the ecological balance of the ecosystem. In addition, conservation entails active management of the biosphere with the aims of maintaining maximum species diversity and genetic diversity within a species, including the maintenance of biosphere functions such as ecosystem functions and biogeochemical cycles (Allaby 2010). Based on this, there are several important points that must be considered in conservation: natural resources; inheritance by the next generation; and the balance of ecosystems, biosphere, and species.

Related to these points, various conservation adaptation models and approaches emerged. Some of them are social community approaches, regional approaches, approaches to protecting forests and water resources, approaches for the purpose of pre-disaster actions, cultural approaches, approaches to maintaining germ plasm and genetic diversity, and many more. Conservation involves not just using one type of approach but combining various types of them. In order to combine several of those approaches, then, a species-based approach combined with local wisdom-based area conservation was used. Species-based conservation means conservation efforts with the aim of saving and protecting certain animal or plant species. In this approach, the related terms include "umbrella species," "flagship species," and "keystone species."

An umbrella species is a species whose distribution or range is broad, so that it covers a significant area (Roberge \& Angelstam 2004); birds and several types of mammal that are classified as high-level vertebrate species are examples of umbrella species (Chase et al. 2000, Suter et al. 2002). Flagship species are iconic and characterize a particular area; such species are ambassador species that are often used as tourist attractions or icons to raise conservation funds, and they symbolize a landscape's habitat (Bowen-Jones \& Entwistle 2002, Walpole \& Leader-Williams 2002). Keystone species are species that play an important role in the structure, function, and productivity of an ecosystem. If this species is lost, it will cause significant changes in the biological structure of the ecosystem; therefore, conserving this species will protect the structure and function of wider habitats (Mills et al. 1993, Libralato et al. 2006).

Based on the various types of species-based approaches, their main similarity is the goal, i.e. habitat protection. This matter means protecting the region as their homes will automatically save the organisms that live there (Shogren 1998). So, it is essential to form an effective habitat rescue effort to have a broad impact on the region's conservation. Because these animal and plant species cannot automatically save their habitats, the most critical role is top-predators or super-predators, namely humans (Darimont et al. 2015, Smith et al. 2017). There is much approach to encounter the damaged habitat, but humans are still the 
leading role in conservation. Thus, the territorial or habitat approach must be implemented with human rules, and these rules must be following the rules of conservation. Therefore people who lived in ancient times created local wisdom as a rule to maintain habitats. Maintaining a habitat entails protecting all species that live in it.

\section{Moluccan Scrubfowl conservation}

Moluccan Scrubfowl (Eulipoa wallacei) is one of the endemic bird species found in some of the islands in Maluku (Coates et al. 1997, White 1998). The bird was intensively studied for several years near Kailolo Village (Heij 1995, 2001, 2005, Rompas \& Moeliker 1997), and successfully reintroduced in Haruku Village (Heij 2005a, Heij 2005b), and then, the rate of successful reproduction and other habitat factors that are still not widely known related to their activities were continuously studied (Saiya 2013, Verboom \& Heij 2016, Verboom et al. 2017).

The International Union for Conservation and Nature lists its status as vulnerable to extinction. The trend of Moluccan Scrubfowl population growth shows a declining pattern from year to year. One of the locations in Maluku where Moluccan Scrubfowl can be found is Haruku village, Haruku Island, Maluku Province. The village has sandy beach structures and ramps that make a suitable nesting ground for Moluccan Scrubfowls. This area is an important research area and breeding site of Moluccan Scrubfowl that are guarded and maintained by the kewang of Haruku village.

The kewang are the guardians of the environment who are raised based on customary village rules (Zerner 1994, Harkes \& Novaczek 2000). In general, every village in Maluku has kewang, who are also referred to as rangers. The task of the kewang is to maintain and regulate the use and protection of natural resources in the sea and on the land (Batiran $\&$ Salim 2020). They employ customary regulations known as sasi, which are ordinances or prohibitions related to certain natural resources. They are part of the efforts invested to preserve the population in order to maintain the quality of biological resources (Zerner 1994, Libralato et al. 2006) such as animals and plants. Sasi are a tradition that has been carried out for generations by the people of Maluku.

The Moluccan Scrubfowl egg-laying habitat is located at the river estuary sandbar, bordering the sea. However, in recent years, the existence of the sandy beach continued to be threatened. It not only reduces the volume of sand on the beach but also washes away a lot of Moluccan Scrubfowl eggs, diminishing the population and reducing the number of breeding birds.

If this process is left unattended without any recovery effort, it will eventually eliminate the entire egg-laying habitat of Moluccan Scrubfowl, which loss will also affect the population of the species. At this point, the active role of indigenous people is significant in controlling the abrasion and preventing the loss of the entire habitat. Kewang Haruku, which is supported by the indigenous people, took the first initiative to save the habitat, which was then welcomed by several researchers, who have conducted research at the location. This was also recognized by a former minister of the environment of the Republic of Indonesia, who said that "We believe by enabling nature, man [is] enabling himself" (Salim 1982). 


\section{The importance of the species' existence in its habitat}

Efforts to save habitats are a reasonable first step to save a species, because the sustainability of a species is closely related to the sustainability of its dwelling place, i.e. its habitat, which is an ecosystem unit with the species that live therein. All animals can only live in an area if basic natural resources are available, i.e. food sources, water sources, and shelter; they can adapt to extreme climatic conditions that occur at any time and can even defend and protect themselves from predators (Morrison et al. 1999). This is contrary to human existence, which has a high adaptability so that changes in habitat such as land conversion will not easily interfere with the existence and endurance of humans in an area. This is the difference in vulnerability between animals and humans, which is seen ecologically. For this reason, in an effort to reconstruct a damaged or threatened habitat, all elements needed by the animal that should be protected must be taken into account in the initial planning stage.

However, it is true that extinctions occur as a result of natural selection. This is consistent with Darwin's theory of evolution that individuals who can survive or adapt well will continue to survive, while those who cannot adapt will go extinct, so it can be seen that natural selection will determine which species continue to exist (Darwin \& Wallace 1858, Williams 2008).

However, if we look at the rate of animal extinction in the past few decades, it can be seen that human treatment of ecosystems has accelerated animal extinction (Wright 1990, Vitousek et al. 1997, Brashares et al. 2001, Ceballos et al. 2015). In addition, another factor in the loss of an animal species is related to the change in its trophic position. This also affects the balance of the ecosystem, because a role is lost, and the interactions between the various components of the ecosystem are disrupted (Nilsson \& Grelsson 1995, Ives \& Carpenter 2007). In this study, we focus on indigenous people's efforts to reconstruct the damaged Moluccan Scrubfowl egg-laying habitat, as well as, how the current condition of the landscape is being conserved by them.

\section{Methods}

This research took place on the coast of Haruku Village, Haruku Island, Central Maluku Regency, Maluku Islands, Indonesia (Figure 1). This location is protected by the indigenous people in Haruku Village. This is because, for a few decades, many Moluccan Scrubfowl have come to this coastal area to lay eggs, and since then, the people have really taken care of the area. In fact, many studies by local and international researchers have been conducted in this area. The area takes the form of a sandbar stretching up to an estuary, with dominant vegetation in the form of nipa palm (Nypah fruticans), sago (Metroxylon sagoo) and coast cottonwood (Hibiscus tiliaceus). The observation period of this study began before the abrasion disaster occurred in 2009 and continued until the end of 2019 and the beginning of 2020. We used a time series research design, which enabled the reconstruction of the location based on regular observations and monitoring by the researchers. 


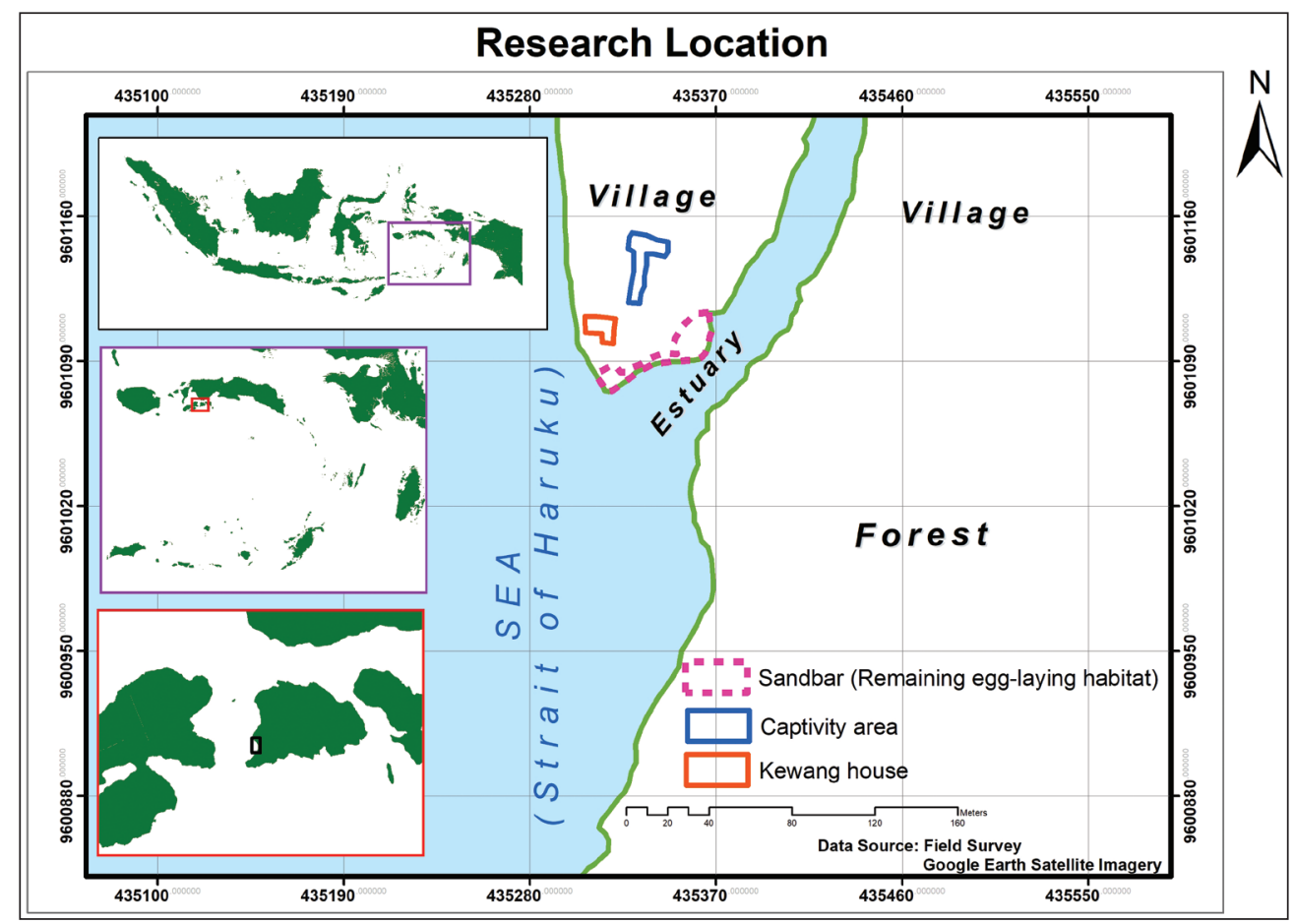

Figure 1. Map of the location (Drawings: H. G. Saiya. Modified from Saiya et al. 2016) 1. ábra A vizsgált terület elhelyezkedése (ábrák: H. G. Saiya. Saiya et al. 2016 alapján, módosítva)

The observations focused on habitat abrasion, savable areas, and people's responses to the occurrence of abrasion. The type of observation carried out was participatory observation, which involved living among indigenous people over a certain period where the researcher could record the responses of indigenous people and could jointly work with them. Furthermore, we used an open interview system, including questions on the knowledge of the Moluccan Scrubfowl and on the conservation efforts that have been carried out, the abrasion disasters, and the habitat reconstruction efforts of the people. The selected key informants were the kewang, representatives of the customary adat government in the village, and people, who participated in reconstruction of the habitat.

The data analyses included two phases. First, a descriptive analysis was used to systematically compile and convey the results of the interviews, and second, a remote sensing technique was applied for obtaining information about the objects without direct contact (Lillesand et al. 2004). Remote sensing was used to analyze the spatial pattern of the abrasion process, which was also supported by field observations. The remote sensing technique involved the interpretation and digitization of GeoEye and Google Earth satellite images, collected from 2009 to 2018. After conducting a geometric correction process, we calculated the surface of the reduced area. The analysis was done in ArcGIS 10.3 ESRI license and the Universal Map Downloader. We used the Garmin 68S GPS during fieldwork. 


\section{Results and Discussion}

\section{Description of Moluccan Scrubfowl (Eulipoa wallacei)}

The morphology of Moluccan Scrubfowl as discovered by Wallace in 1858 is as follows: the front of the head and neck are a grayish, greenish brown, while the back is light brown. The nape of the neck and upper back are slightly grayish and blackish green. The middle of the back, wings, and external mesh of some tertiary castaneous are dark in color and most of the edges of the fur are bluish gray. The body top tail feathers, chest, and abdomen are grayish, whereas the small, tertiary feathers and tail are a pale brownish green. The middle of the abdomen is white. The primary bristles are blackish brown patches or bordered with grayish white on the outside. They have a yellow beak and black legs. The body length is $330 \mathrm{~mm}$ and the wing length is $190 \mathrm{~mm}$ (Gray \& Wallace 1860, Gray \& Wetmore 2011). The iris is light brown, the beak is opaque yellow, the front legs are yellow-black, and the back legs are yellowish (Ripley 1960).

Moluccan Scrubfowl is distributed throughout Halmahera, Meiti, Ternate, Bacan, Buru, Boano, Seram, Ambon and Haruku (Coates et al. 1997), inhabiting tropical mountain forests (Heij \& Rompas 1999) up to a height of 750-1,650 m. Moluccan Scrubfowl lives alone or in pairs, is shy and difficult to separate from its nesting community. People almost never found this bird in the forest, because it lived in mountain forests with an altitude of 200300 meters above sea level in a lime formation (Toxopeus 1922). These birds also cannot be tamed or locked in cages (Valentijn 1726). Villagers are able to detect the presence of Moluccan Scrubfowl by its call (Heij \& Rompas 1999). This species has a monogamous mating system. The pair formation on Haruku Island takes place throughout the year with a peak during the dry season, i.e. October-April (Dekker \& Brom 1990, Dekker 1991). At nights, these birds leave the forest, fly to the beach to make holes and lay eggs. Then, they

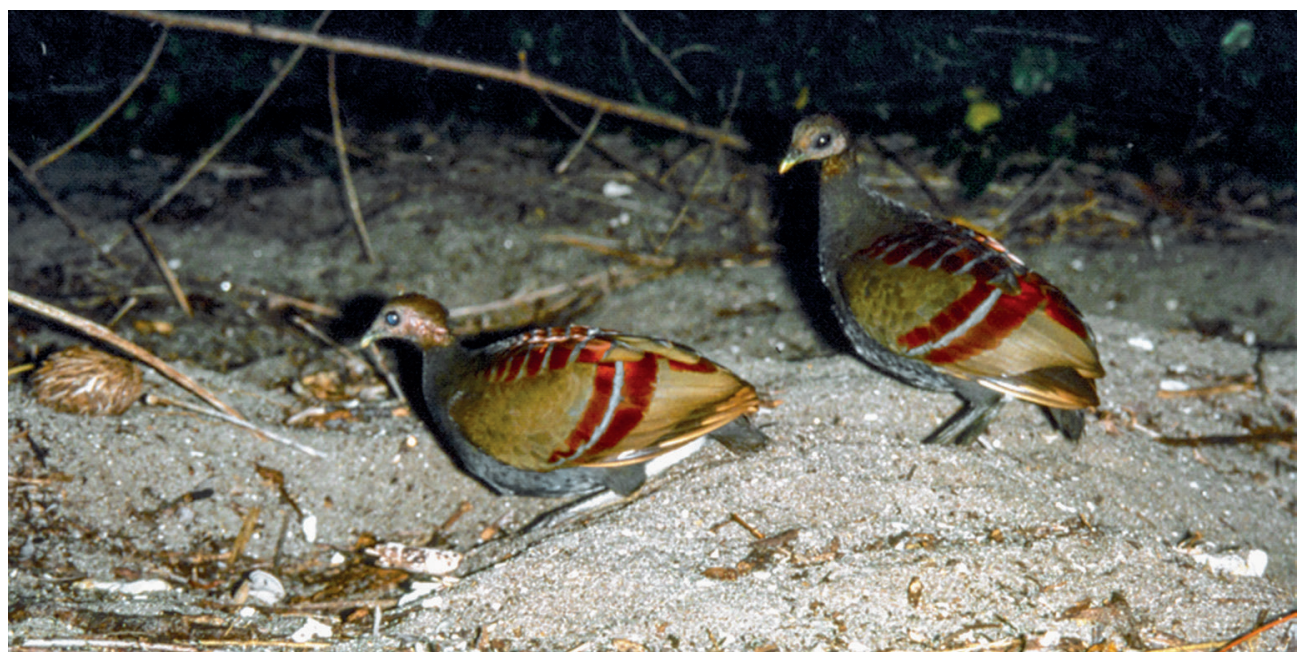

Figure 2. Moluccan Scrubfowl. Photo taken in Kailolo, by C. J. Heij (Heij 2001)

2. ábra Maluku-szigeteki ásótyúk. Fotó: C. J. Heij készítette Kaiolo-n (2001) 


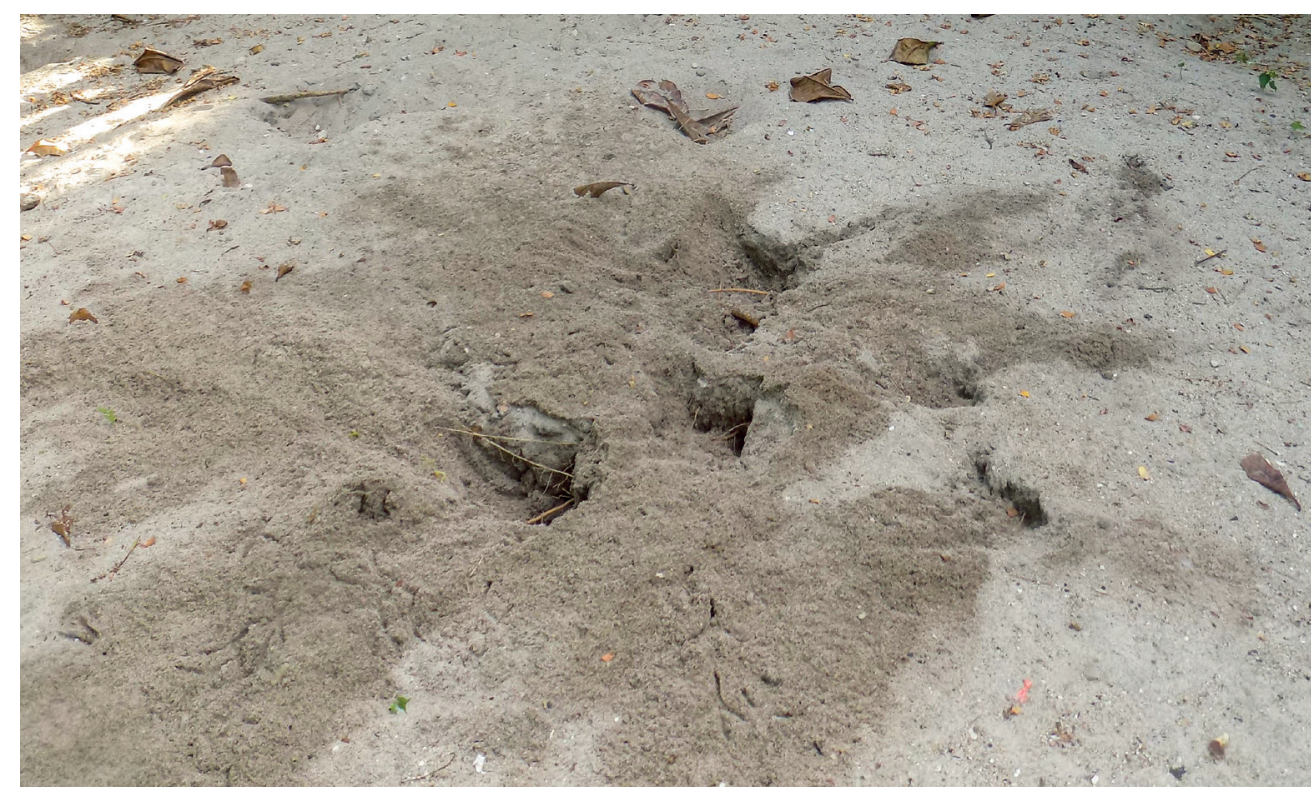

Figure 3. Moluccan Scrubfowl dig holes to lay eggs (Photo by: H. G. Saiya, 2019)

3. ábra A maluku-szigeteki ásótyúk fészekcsészét kapar a tojásainak (Fotó: H. G. Saiya, 2019)

cover the holes with sand, also partially hiding their footprints to confuse predators (Baker \& Dekker 2000, Wallace 2016) (Figure 3).

Moluccan Scrubfowl females also dig multiple dummy holes to protect their eggs from predators and they do not build sand dunes like other megapode types (Dekker \& Dekker 1990, Dekker 1991) (Figure 3). After egg-laying, the birds fly back to the forest at sunrise (Hoyo et al. 1994). The parents do not incubate the eggs that are kept warm by the heat obtained from the surrounding sand.

Based on the presence of Moluccan Scrubfowl and its habitat conditions, this megapode is an umbrella species. Thus, a species-based conservation approach can be used. This option was chosen because of its wide home range and many tree habitats, from mountain forest vegetation types to stable coastal vegetation. So, efforts to conserve the Moluccan Scrubfowl habitat will also preserve forests and coastal habitats.

\section{Customary rules by the indigenous people}

The indigenous people of Maluku are the type who have the potential to be effective in preserving the environment and can implement a system of social harmony based on local wisdom and environmental control. Since long ago, the people of Maluku who live on the islands have grown their local wisdom in accordance with their natural conditions and needs. The local wisdom is generally referred to as sasi. Sasi means customary rules governing the management and use of natural resources at the sea and on the land, the rules of which are made based on customary agreements and only applied to certain customary areas within the village (Xiuping et al. 2010, Saiya \& Heij 2017) The rules of sasi differ among villages. Sasi 
is a cultural institution that regulates the use and management of living natural resources and the environment, i.e. sasi can also be understood as management for the sake of achieving quality products, quality natural resources, and economic values. Sasi also means teaching values related to a strong work ethic in society. This means that besides using effective and efficient production methods, people also pay attention to and pursue the highest quality of human work (Pietersz 2010, Rugebregt 2013).

Interviews with several traditional leaders taught us that sasi has existed in Maluku since immemorial time and is a form of joint commitment by indigenous people, traditional leaders, and government members in the village. Sasi also contains restrictions and sanctions in the form of fines that must be paid in case of violations. Fines can be in the form of goods, money or community work in the village. This is based on the realization that without their environment they cannot live properly, so until now, sasi has been maintained from generation to generation. In general, sasi is divided into land sasi and sea sasi. Land sasi covers forest products such as wood, rattan, cloves, nutmeg, and tubers. Sea sasi covers marine products such as fish, sea cucumbers, sea snails, and pearls. Then, after religion entered the Maluku Islands, the indigenous people switched from animistic beliefs, so the rules in sasi began to be harmonized with their religious ways. The fines obtained from the implementation of the sasi rules would also be used to meet the needs of church or mosque.

Sasi is closely related to the kewang. Kewang (Figure 4) is a position that is within the customary adat government that functions to regulate and oversee the implementation of the rules of sasi. So, the kewang also monitor and protect natural resources on the land and at the sea. Kewang and other types of position in the customary government are inherited based on descent, so not everyone in the community can easily hold certain positions in the customary order. The kewang usually consists of one head and several members. Moreover, they have to make regulations related to the use and control of natural resources. Sasi is a general term for the rules made by the kewang. Some simple examples of sasi rules are as follows:

1. It is forbidden to take any kind of fruit that is still unripe.

2. People are prohibited from cutting down trees that bear fruit before obtaining permission in the customary adat manner.

3. It is prohibited to cut off the roof/fronds of young sago before obtaining permission from the owner and also permission from the kewang.

4. It is prohibited to catch small-sized fish that are not suitable to be caught.

5. People must not take sea cucumbers in areas of water that have been restricted by the village government; sea cucumbers in those areas must be allowed to develop.

6. It is forbidden to take a sea snail that is still small in size and not suitable for consumption.

Related to the sasi for Moluccan Scrubfowl, information from several members of the kewang and the people in Haruku told us that Moluccan Scrubfowl has not been present in Haruku Village decades ago. However, after the emergence of the sandbank around the river estuary in Haruku Village, many Moluccan Scrubfowls colonized the area. So, the members of the kewang in Haruku began to clean the sandy area, which was quite wide, of the various creepers, shrubs, and grasses that grew there. At that time, Moluccan Scrubfowl had not been incorporated into the customary adat rules, so the people of Haruku took the eggs and birds 

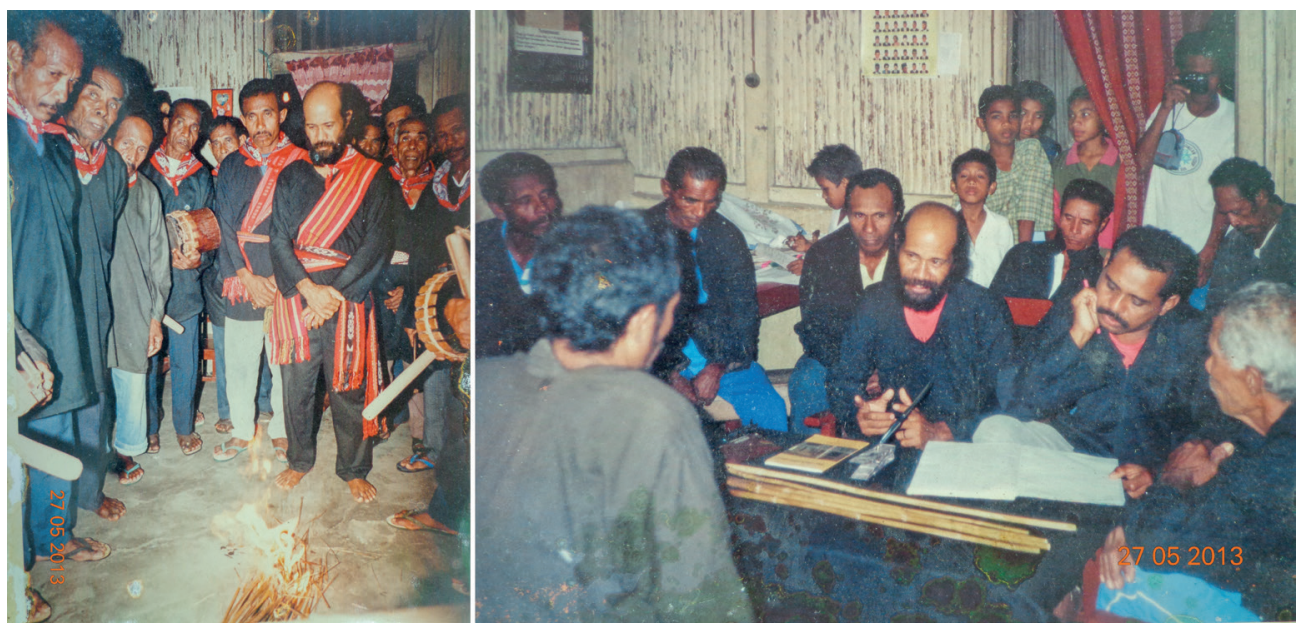

Figure 4. The Kewang (Source: Documentation from Kewang Haruku)

4. ábra A Kewang (Forrás: A Kewang Haruku dokumentációja)

freely. Some of them even deliberately went to the forest trapping Moluccan Scrubfowl. Then, they recognized that the Moluccan Scrubfowl are vulnerableand the kewang set a rule for the protection of these birds. The rule states that Moluccan Scrubfowl eggs and specimens should not be taken for consumption and sale. The rule applies until now and even predatory animals that prey on Moluccan Scrubfowl are also kept away from the egg-laying areas. Gradually, Moluccan Scrubfowl has become one of the characteristic sasi of Haruku Village.

\section{Positive idealism for saving the habitat}

In 2009, the Moluccan Scrubfowl egg-laying habitat took the form of a beach with vast stretches of sand extending south to the edge of a forest cliff that borders the sea and river estuary (Figure 5). The egg-laying site extends to north where is the kewang house and it is bordered by a pig farm owned by several families living nearby. The beach vegetation at that time was dominated by Pandanus sp., tropical almond (scientific name $=$ Terminalia catappa; Ambonese = ketapang), coast cottonwood (Hibiscus tiliaceus), Calophyllum inophyllum $($ Ambonese $=$ bitanggor, Javanese $=$ nyamplung $)$, nipa palm (Nypah fruticans), sago (Metroxylon sagoo) and coconut (Cocos nucifera), with a sandbar area of $6,675 \mathrm{~m}^{2}$, according to the results of calculations using the remote sensing technique.

The observations and interview results showed that the condition of the egg-laying habitat was very stable in 2009 and before. In fact, many village activities were carried out in the area in order to maintain the sustainability of the area. Some people from Ambon Island also came to the area for recreation. Of course, they had to get permission from the kewang before they could enter the area. The kewang also required them not to litter in the area, and if this rule was violated, they would be subject to the customary sanctions according to the rules written in sasi. In addition, the kewang severely limited the number of visitors from Ambon to prevent damage of the ecosystem. However, research trips and environmental 

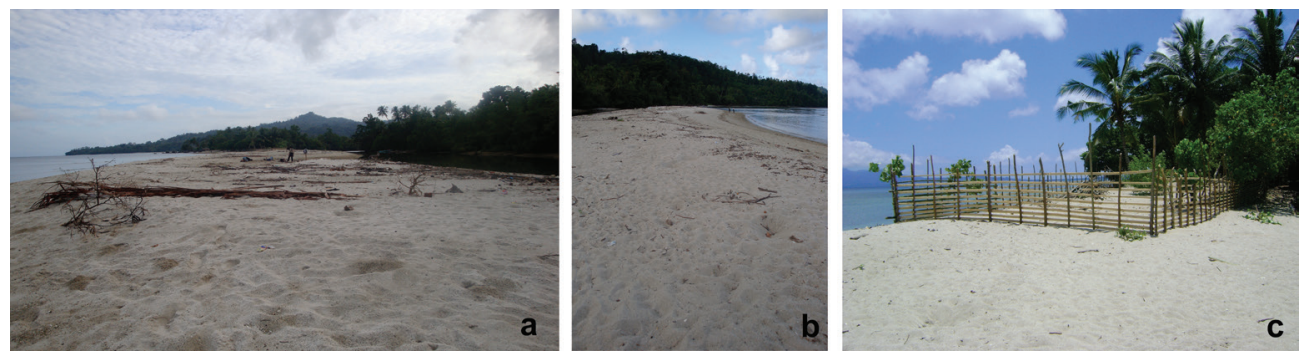

Figure 5. The condition of the sandbar in 2009 (Photo by: H. G. Saiya, 2009); a - sandbar seen from the south, $\mathrm{b}$ - in the middle of the sandbar, $\mathrm{c}$ - the northern part of the sandbar

5. ábra A homoknyúlvány állapota 2009-ben (Fotó: H. G. Saiya, 2009); a - déli, b. - középső, c északi rész

learning are not limited by the kewang.

This location is often visited by local and international researchers who come to conduct various studies. The research targets in this location are diverse, including mangrove research; sago research; river and estuary ecosystem research; research on lompa fish (Trissina baelama); sea turtle research; crab research; coral reef research; research on various mollusc species spread across the mangroves, river, ocean, and surrounding ecosystems; research on local wisdom; bird watching; and specific research related to Moluccan Scrubfowl. Many researchers have come to this location to search for Moluccan Scrubfowl. They make special observations of the birds' egg-laying behavior at night on the coast. In addition, children in Haruku Village often come to this location learning from various books donated by researchers. This location is a natural laboratory for all people.
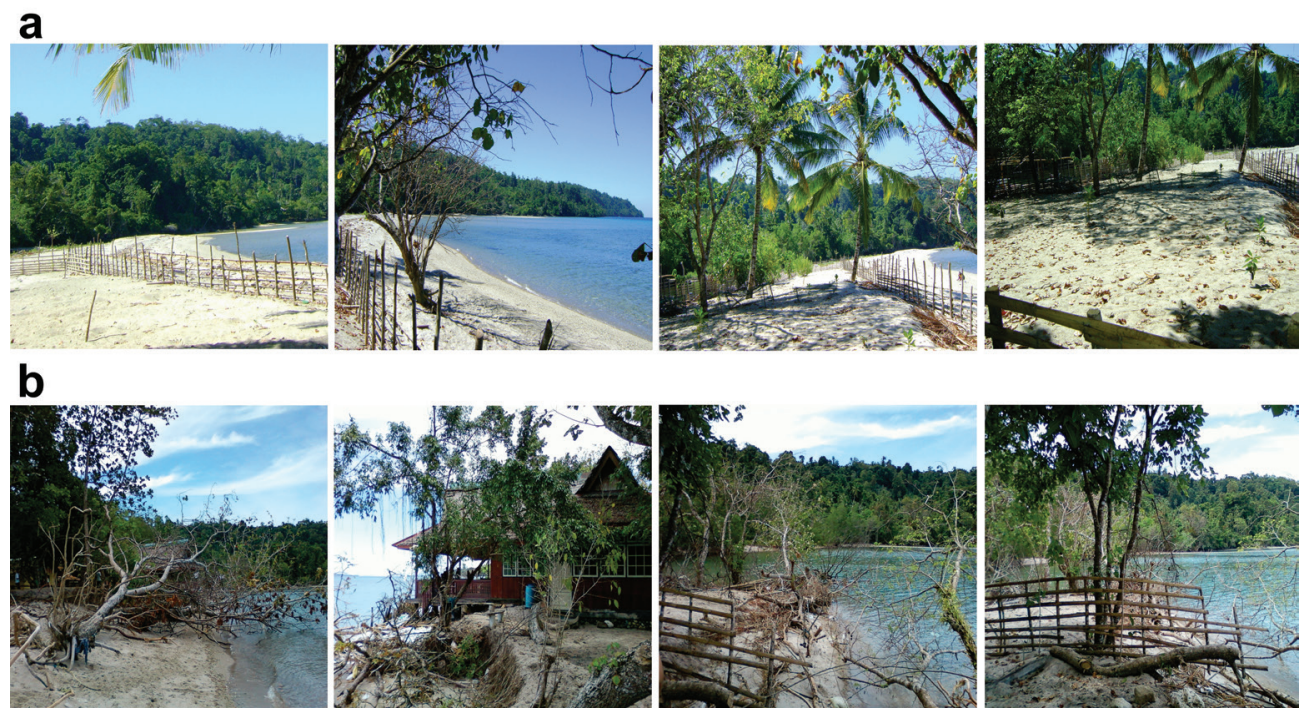

Figure 6. Before and after photos: a - before abrasion in 2010 (Photo by: H. G. Saiya); b - after abrasion in 2010 and 2011 (Photo by: H. G. Saiya \& W. Nitalessy)

6. ábra Előtte-utána fotók: a - Abrázió előtti állapot 2010-ben (Fotó: H. G. Saiya), b - Abrázió utáni állapot 2010-ben és 2011-ben (Fotó: H. G. Saiya \& W. Nitalessy) 
However, at the end of 2010 to mid2011, massive abrasion occurred eliminating most part of the sandbank area (Figure 6).

After this event, the remaining sandbar area amounted to $1,504 \mathrm{~m}^{2}$ in 2012 , then up to 2014, the sandbar area further decreased to $1,170 \mathrm{~m}^{2}$. According to the last calculations from 2018, the remaining area of the sandbar was $1,161 \mathrm{~m}^{2}$. Satellite images of GeoEye and Google Earth confirmed these results (Figure 7). The direction of the estuary flow has also been changed as a result of this condition.

These conditions prompted the indigenous people of Haruku Village to take various actions. Under the coordination of the kewang, they began to reconstruct the sandbar area in 2011. However, while abrasion was taking place, they built temporary barricades made of sacks filled with sand and stone, then ar-

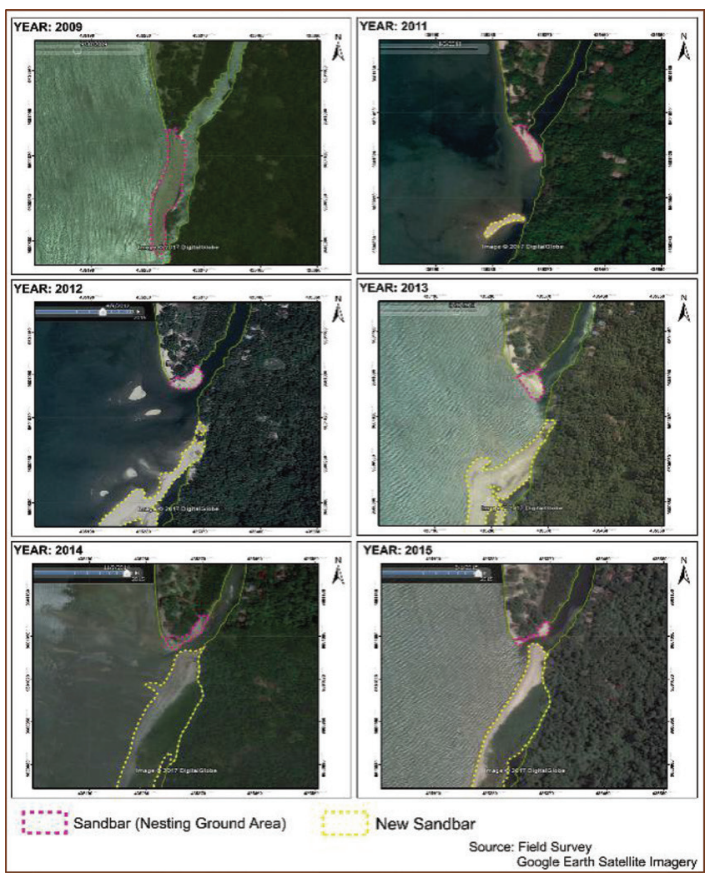

Figure 7. Time series record from satellite (Source: Google Earth)

7. ábra Műholdfelvételek (Forrás: Google Earth) ranged them along the remaining coastline area. They sought help from the local government to make embankments along the remaining beach area. Unfortunately this action resulted in a temporary solution. After 2016, abrasion increased again destroying the already poor quality beach embankments. Most of the sand substrate was swept away by the waves (Figure 8).

The kewang house was also damaged by the abrasion (Figure 9). With the assistance
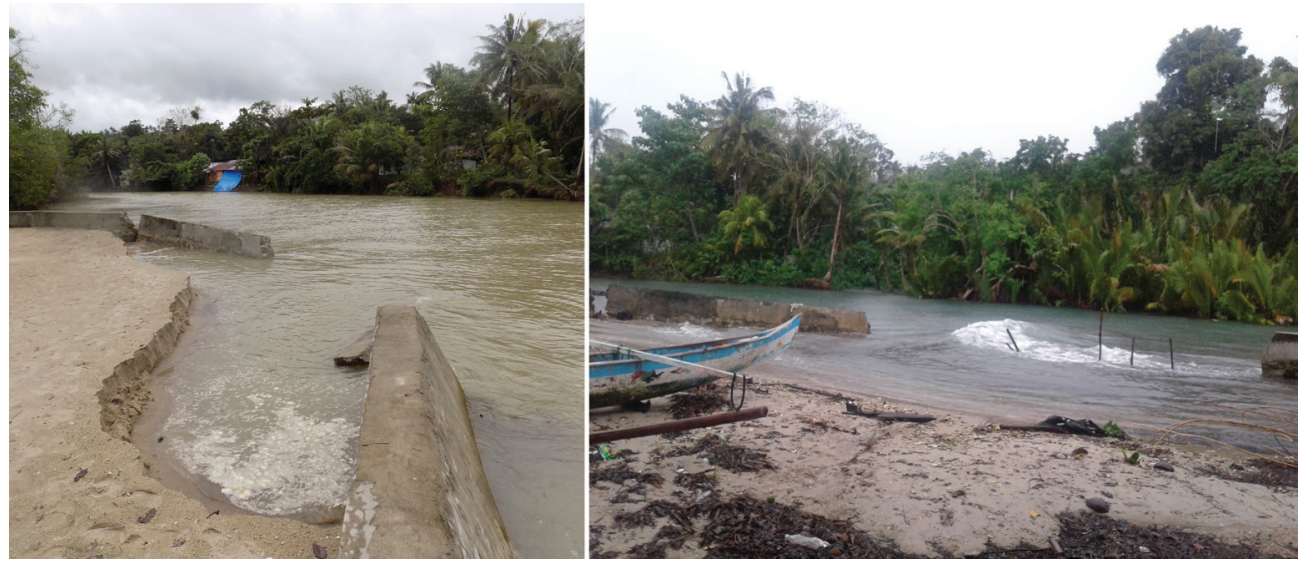

Figure 8. Abrasion in 2016 (Photo by: H. G. Saiya)

8. ábra Abrázió 2016-ban (Fotó: H. G. Saiya) 

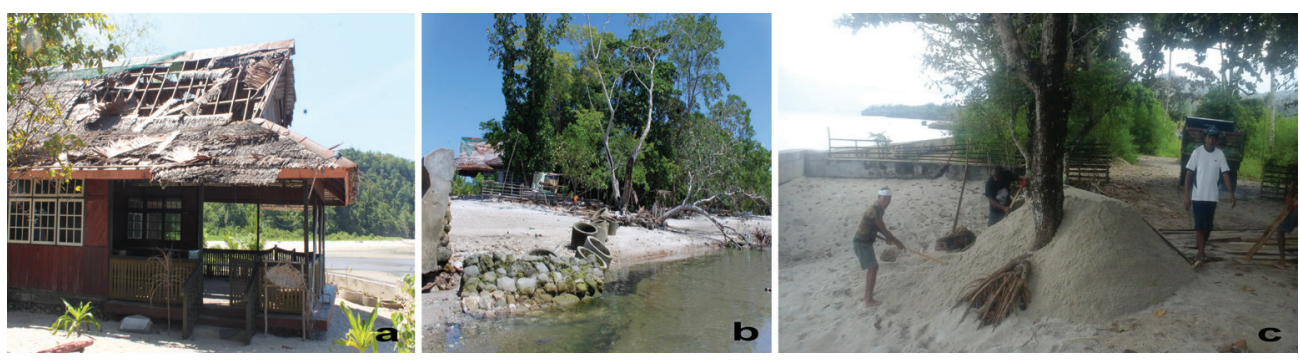

Figure 9. a - Kewang house was broken, b - the occurrence of abrasion, c - local people transport sand from other locations to be relocated in the beach (Photo by: H. G. Saiya)

9. ábra a - A megrongálódott Kewang ház; b - abrázió; c - a helyiek máshonnan szállítanak homokot az újratelepítéshez (Fotó: H. G. Saiya)

of BirdLife Indonesia and the Marinus Plantema, sand was brought to the location to reconstruct the area. For this activity, all aid workers in the village were mobilized to transport sand taken from other parts of the village bordering the forest to the coast (Figure 9). The reconstruction activities included the replantation of the coastal vegetation. The local people received assistance from the Ministry of Maritime Affairs and Fisheries related to the recreation program for coral reefs that can help to break up the waves to prevent the are from abrasion.

Although most of the egg-laying habitat was lost, Moluccan Scrubfowl has not disappeared from the area. In fact, after the massive abrasion events in 2010 and 2011, no Moluccan Scrubfowl laid egg here. However, other activities, including the action of kewang routinely moving the eggs of the Moluccan Scrubfowl found along the eroded sandbank to a safer area and monitoring the hatching, successfully increased the number of breeding birds in the area. In addition, special captive breeding of Moluccan Scrubfowl was also organized and the birds were released into nature. This was initiated jointly with the local university as well as several researchers who regularly came to monitor this location.

\section{Monitoring reconstructed locations}

The sustainability of a location that has undergone reconstruction needs to be monitored. The aim is to validate whether the habitat has stabilized or not and if it is still experiencing disturbances. The results of the 2019-2020 monitoring on the reconstruction of the Moluccan Scrubfowl egg-laying habitat highlighted the following (Figure 10):

1. The quality of the embankment is poor and they can be quickly damaged by sea waves. The community aims to improve the damaged embankment.

2. An ongoing replantation of coral reefs is being carried out, located around the eroded area.

3. The collection of Moluccan Scrubfowl eggs in the area along the eroded sandbank continues by the kewang. All of the eggs are buried again in captivity. However, the new location is still close to the egg-laying habitat. Moreover, the location may still be threatened by abrasion.

4. The release of chicks continues, leaving only two birds in captivity. The aim is to show 


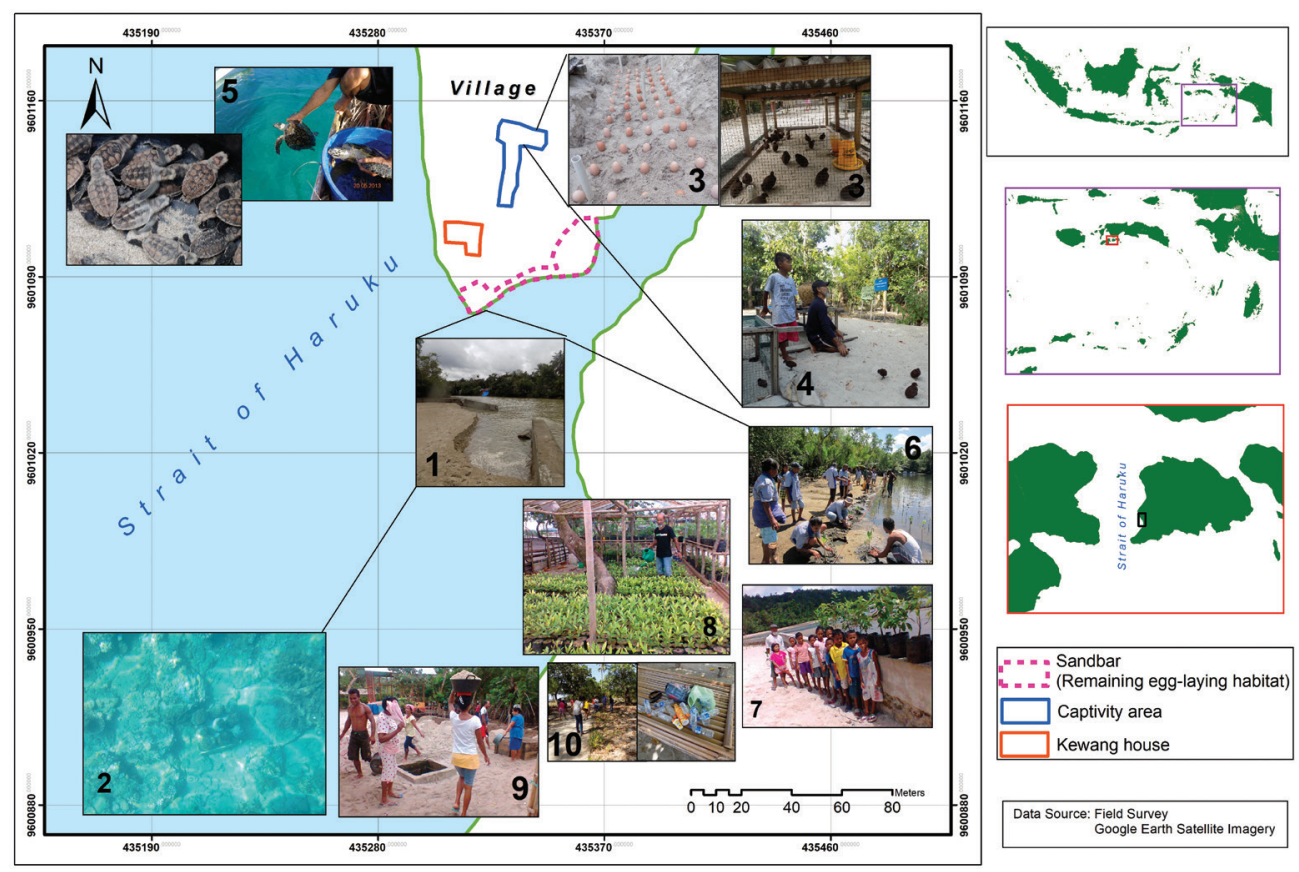

Figure 10. The results of monitoring in 2019 and 2020 (Drawings by: H. G. Saiya) 10. ábra A 2019-es és 2020-as felmérések eredményei (ábrák: H. G. Saiya)

the existence of the Moluccan Scrubfowl. When researchers, academics, and outsiders want to come and see the birds, they can immediately see them in captivity without going to the forest or staying overnight to wait for the birds to come and lay eggs. These two birds will be released in turn, once there are substitutes, which will be chosen from among the newly hatched chicks.

5. Aside from being only egg-laying habitat for Moluccan Scrubfowl, the sandbars that are lost due to abrasion are also spawning grounds for sea turtles. So, at the time of the abrasion disaster, the kewang found many turtle eggs swept away by the waves. After the habitat underwent gradual reconstruction, turtle eggs that continue to be found in the area are collected by the kewang and transported to a safer location next to the Moluccan Scrubfowl captive breeding area. Turtles also hatch in the area, and usually the kewang will release them, involving children of elementary and secondary schools, along with other people who are interested in the releasing of the turtles.

6. There are kewang nurseries for mangroves around the Moluccan Scrubfowl captive breeding area, and the community voluntarily planted mangroves along estuary areas bordering the Moluccan Scrubfowl nesting habitat. Considering that mangroves are a good antidote to abrasion, these activities are carried out, as well as, caring for and protecting mangrove seeds that have been planted.

7. The kewang initiated early education about being environmentally conscious for elementary and junior high school children in Haruku Village, so that they can be involved in every activity. In addition, the kewang also formed the Little Kewang, which trains 
children to protect and preserve the natural environment. These children report activities they consider as acts of environmental destruction or violations of the customary rules related to the natural environment.

8. The kewang created a seedling house for various types of mangroves, cloves (Syzygium aromaticum) and nutmegs (Myristica fragrans).

9. The local people continue to independently procure sand (Figure 9).

10. The kewang conducts routine garbage collection programs along the coast of Haruku village to prevent threats to the health and stability of the coastal habitats.

Based on various conservation efforts undertaken by indigenous people in Haruku Village, they have used their local wisdom to maintain the Moluccan Scrubfowl nesting habitat. An abrasion disaster that removed most of the coastal habitat made people more intensely concerned about the area. The engagement, compliance, and voluntary desire of indigenous people to save coastal habitats in a form of social security action used in the environmental field. The people began the action with a species-based conservation approach but continued with an area-based conservation approach and local wisdom/customary law, so that the people not only directly saved the Moluccan Scrubfowl species, but also saved the entire existing coastal habitat. The local wisdom of indigenous people is a form of global wealth

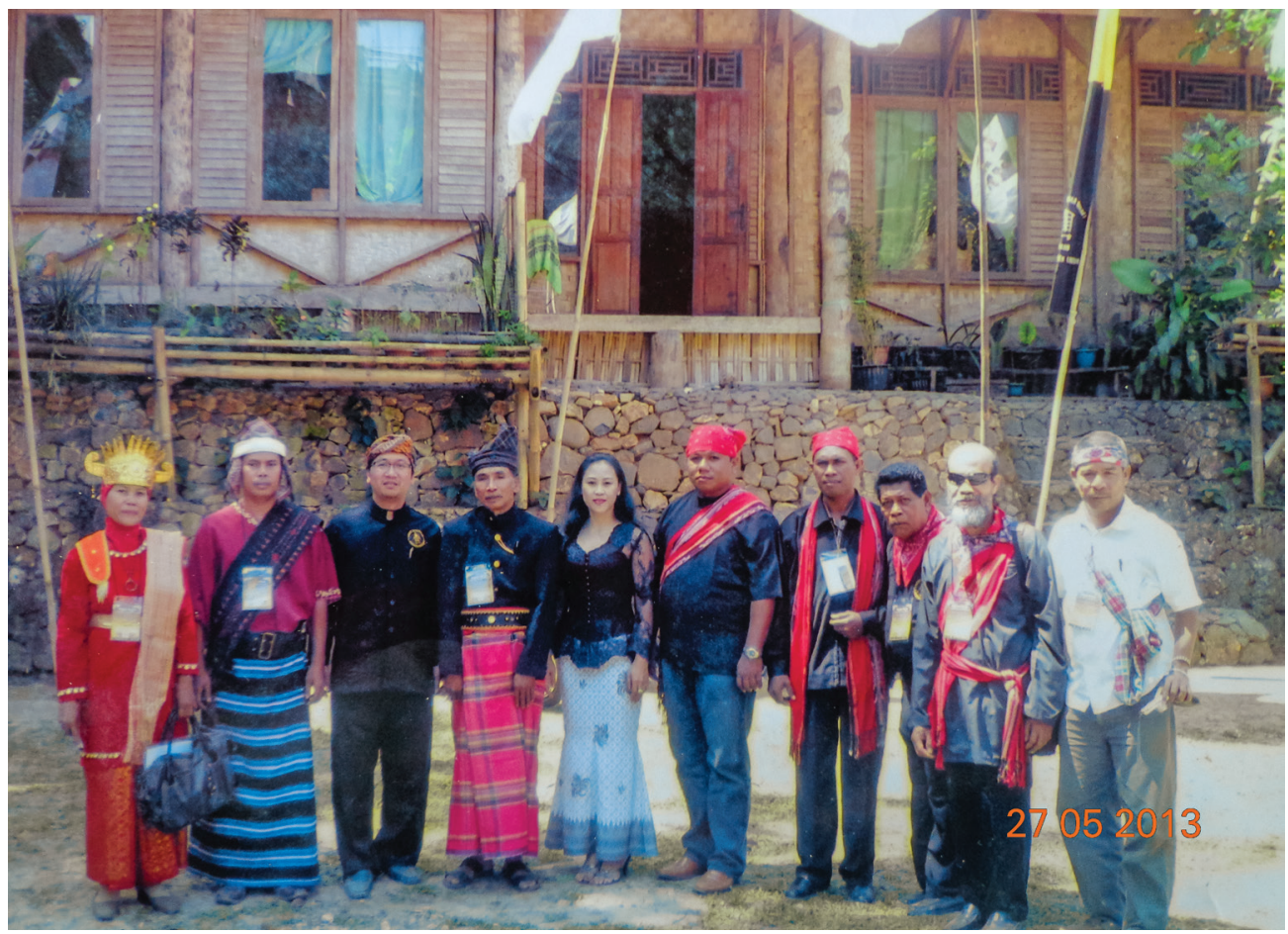

Figure 11. Kewang of Haruku on a conference of Aliansi Masyarakat Adat Nusantara (AMAN) (The leader of Kewang Haruku, second from the right side). Source: Documentation from Kewang Haruku

11. ábra Kewang Haruku egy AMAN által szervezett konferencián (A vezető jobbról a második.) Forrás: A Kewang Haruku dokumentációja 
that makes an important contribution to achieving sustainable development, for the culture related to environmental conservation that has developed in indigenous people should not be eliminated (Lertzman \& Vredenburg 2005). However, the tendency to work directly with indigenous people/local communities has gradually disappeared as nongovernmental organizations (NGOs) have come to be prioritized and considered as the main drivers of conservation. Conservation priorities change and lead to conservation strategies with a larger scale and more developed science, but we should remember the social reality of indigenous people in determining their own conservation agenda (Chapin 2004). So, what exactly is the position of the indigenous people?

The position of indigenous people is actually as conservationists, and their position must not be changed. Third parties who come to help can only act as companions. In this case, scientific organizations such as BirdLife Indonesia and the Marinus Plantema foundation, as well as several academics, were assistants who together sought solutions against habitat destruction, but the ones who determined and implemented the solutions were the indigenous people of Haruku Village. States and academics should not treat indigenous people (Figure 11) as clients, but they should be involved at all levels of decision making (Mauro \& Hardison 2000), whether it is related to the natural environment, spatial uses, or various other matters. Moreover, indigenous people make up communities that are truly associated with their territories for a very long period. This is what makes them to truly understand what is happening in their area (Colchester 1994, 2013). Thus, even to carry out conservation efforts, indigenous people must be socially and culturally prepared. All they need are assistance and monitoring.

\section{Conclusion}

Conservation is clearly a continuous effort that must be made to maintain the sustainability of natural resources. Habitats that are threatened with damage can be revived through intense habitat reconstruction efforts. In the case of egg-laying habitats for Moluccan Scrubfowl affected by abrasion, the main conservation actors are the indigenous people. They have lived together with their environment and depend entirely on the natural products around them to meet their daily dietary needs, so even the smallest environmental changes will have a direct impact on them.

The abrasion process that destroyed the Moluccan Scrubfowl egg-laying habitat left a remaining sandbar with an area of $1,161 \mathrm{~m}^{2}$, which is approximately $17 \%$ of the area of the initial sandbank of $2009\left(6,675 \mathrm{~m}^{2}\right)$. This not only affected the Moluccan Scrubfowl but also damaged the surrounding support areas by destroying the coastal vegetation; disrupting turtle nesting and even causing the deaths of a part of the population; and causing instability in the estuary conditions and other physical damage. The efforts of the indigenous people in the reconstruction of this area are a step in the right direction.

Despite many obstacles faced over the years, the local wisdom of the indigenous people proves that species conservation based on habitat conservation can be carried out. Even though habitat restoration is a long process, the concrete steps taken by the indigenous 
people indicate that humans are truly responsible for their environment.

Furthermore, the position of indigenous people as conservationists is need to be maintained. Indigenous people must be given the opportunity to decide what should be done to overcome all forms of disturbance in their habitat. NGOs, researchers, and academics should only monitor the processes and provide input. Indigenous people should not be used as a tool for fulfilling the work programs of NGOs or governments. In addition, they should not be used as objects, but rather as partners. They are an important part of the power of environmental conservation.

Finally, it can be seen that the Moluccan Scrubfowls lay their eggs at these locations because indigenous people invested a huge amount of effort into the reconstruction of the egg-laying habitats of these birds. Indigenous people also built breeding sites to protect the eggs buried by female birds. During these actions, the indigenous people were assisted by various researchers from local universities, so the breeding sites became a research location. Specifically, for the Moluccan Scrubfowl egg-laying habitat, the activities carried out by indigenous people were as follows: making embankments, adding sand to the eroded area, replanting supporting coastal vegetation, and constructing breeding sites.

The community also made efforts to restore the surrounding support areas that were also damaged. The activities carried out were as follows: replantation of coral reefs, establishing turtle breeding sites, creating mangrove nurseries, planting mangroves, setting up nurseries for other plant species such as cloves and nutmegs, picking up trash along the coast, and providing early education for children in how to be environmentally conscious.

The results of this study indicated that conservation is an ongoing collaborative effort involving indigenous people or local communities, i.e. the people who live in the area. Effective conservation is continuously places habitat restoration as its initial objective, so that the intended species will be saved.

\section{Acknowledgement}

The authors thank to BirdLife Indonesia and Marinus Plantema play an active role in handling abrasion. An extraordinary thanks also to all peoples in Haruku Village along with the whole Kewang Haruku. Thanks also to the Head of Kewang Haruku, Eliza Kissya and his son Beni Kissya, as well as Willem Nitalessy, who all helped with the documentation, and thanks also to Elizabeth Hateyong and Rob Vink for all their help in the field. Thank you to Prof. Sangkot Marzuki, who allowed the first author to present this reconstruction activity at the Indonesian American Kavli Frontiers of Science Symposium in Ambon. Also to Herdis Herdiansyah and Donna Asteria that provide help in proofread the manuscript. Finishing the map in this paper is done with facilities at the Geospatial Laboratory, School of Environmental Science. This paper also a part of DIVERLING (Biodiversity for Environmental Sustainability) cluster research activity in School of Environmental Science, Universitas Indonesia. 


\section{References}

Allaby, M. 2010. A Dictionary of Ecology, $4^{\text {th }}$ ed. - Oxford University Press DOI: $10.1093 /$ acref/9780199567669. 001.0001

Baker, G. C. \& Dekker, R. W. R. J. 2000. Lunar synchrony in the reproduction of the Moluccan Megapode Megapodius wallacei. - Ibis 142(3): 382-88. DOI: 10.1111/j.1474-919X.2000.tb04434.x

Batiran, K. \& Salim, I. 2020. A Tale of Two Kewangs: A comparative study of traditional institutions and their effect on conservation in Maluku. - Forest and Society 26: 81-97. DOI: 10.24259/fs.v4i1.8186

Bowen-Jones, E. \& Entwistle, A. 2002. Identifying appropriate flagship species: The importance of culture and local contexts. - Oryx 36(2): 189-195. DOI: 10.1017/S0030605302000261

Brashares, J. S., Arcese, P. \& Sam, M. K. 2001. Human demography and reserve size predict wildlife extinction in West Africa. - Proceedings of the Royal Society B: Biological Sciences 268(1484): 2473-2478. DOI: 10.1098/rspb.2001.1815

Ceballos, G., García, A., Pringle, R. M., Ceballos, G., Ehrlich, P. R., Barnosky, A. D., García, A., Pringle, R. M. \& Palmer, T. M. 2015. Accelerated modern human - Induced species losses : Entering the sixth mass extinction. - Science Advances 1(5): e1400253. DOI: 10.1126/sciadv.1400253

Chapin, M. 2004. A challenge to conservationists. - World Watch 17(6): 17-31.

Chase, M. K., Kristan, W. B. III., Lynam, A. J., Price, M. V. \& Rotenberry, J. T. 2000. Single species as indicators of species richness and composition in California Coastal Sage Scrub birds and small mammals. - Conservation Biology 14(2): 474-487. DOI: 10.1046/j.1523-1739.2000.98312.x

Coates, B. J., Bishop, D. K. \& Gardner, D. 1997. Panduan Lapangan Burung-Burung Di Kawasan Wallacea [Field Guide for Birds of the Wallacea Region]. - BirdLife International-Indonesia Programme \& Dove Publications (in Indonesian)

Colchester, M. 1994. Salvaging Nature: Indigenous Peoples, Protected Areas and Biodiversity Conservation. Discussion Paper - United Nations Research Institute for Social Development.

Colchester, M. 2003. Salvaging Nature: Indigenous Peoples and Protected Areas and Biodiversity Conservation. - Publisher: WRM and FPP

Darimont, Ch. T., Fox, C. H., Bryan, H. M. \& Reimchen, Th. E. 2015. The unique ecology of human predators. Science 349(6250): 858-860. DOI: 10.1126/science.aac4249.

Darwin, C., Wallace, A. R., Lyell, S. C. \& Hooker, J. D. 1858. On the Tendency of Species to Form Varieties; and on the Perpetuation of Varieties and Species by Natural Means of Selection. - Journal of the Proceedings of the Linnean Society of London. Zoology 3: 45-53.

Dekker, R. W. R. J. \& Dekker, R. W. 1990. Conservation and Biology of Megapodes (Megapodiidae, Galliformes, Aves). - Rodopi

Dekker, R. W. R. J. \& Brom, T. G. 1990. Maleo eggs and the amount of yolk in relation to different incubation strategies in Megapodes. - Australian Journal of Zoology 38(1): 1-9. DOI: 10.1071/ZO9900019

Dekker, R. W. R. J. 1991. The Moluccan Megapode Eulipoa wallacei 'Rediscovered'. - Megapode Newsletter 5: 9-10.

del Hoyo, J., Elliott, J. \& Sargatal, J. 1994. Handbook of the Birds of the World. - New World Vultures to Guineafowl. - Lynx Edicions, Barcelona, $2^{\text {nd }}$ edition

Gray, G. R. \& Wetmore, A. 2011. A list of the genera of birds : with their synonyma and an indication of the typical species of each genus / by George Robert Gray. A List of the Genera of Birds : With Their Synonyma and an Indication of the Typical Species of Each Genus / by George Robert Gray

Gray, G. R. \& Wallace, A. R. 1860. List of Birds Collected by Mr. Wallace at the Molucca Islands, with Descriptions of New Species, etc. - Proceedings of the Zoological Society of London, pp. 341-382. http:// biodiversitylibrary.org/page/4254470.

Harkes, I. \& Novaczek, I. 2000. Institutional Resilience of Sasi Laut, a Fisheries Management System in Indonesia. - In $8^{\text {th }}$ Biennial Conference of the International Association for the Study of Common Property IASCP in Bloomington Indiana USA May $31^{\text {st }}$ June $4^{\text {th }}$

Heij, C. J. 1995. The Biology of the Moluccan Megapode Eulipoa wallacei (Aves, Galliformes Megapodiidae) on Haruku and Other Moluccan Islands; Part 1: Scope of the Study and Preliminary Results. - DEINSEA: jaarbericht van het Natuurmuseum Rotterdam : annual of the Natural History Museum Rotterdam 2(1): 14555. http://www.hetnatuurhistorisch.nl/fileadmin/user_upload/documents-nmr/Publicaties/Deinsea/Deinsea 03/ DeinseA_3_1-63_pdf. 
Heij, C. J. 2001. On the Earliest Written Descriptions of the Moluccan Megapode Eulipoa wallacei and Its Peculiar Nesting Behaviour. - DEINSEA: jaarbericht van het Natuurmuseum Rotterdam : annual of the Natural History Museum Rotterdam 8(1): 253-256.

Heij, C. J. 2005a The Biology of the Moluccan Megapode Eulipoa wallacei (Aves, Galliformes, Megapodiidae) on Haruku and Other Moluccan Islands; Part 4: Update of Data until 2005. - DEINSEA: jaarbericht van het Natuurmuseum Rotterdam : annual of the Natural History Museum Rotterdam 11(1): 159-168.

Heij, C. J. 2005b Successsful Re-Introduction of the Moluccan Megapode Eulipoa wallacei at the Haruku Village Nesting Grounds, Haruku Island, Moluccas, Indonesia. - BirdLife/WPA/SSC Megapode Specialist Group Megapode Newsletter 19: 6-10.

Heij, C. J., Rompas, C. F. E. \& Moeliker, C. W. 1997. The Biology of the Moluccan Megapode Eulipoa wallacei (Aves, Galliformes, Megapodiidae) on Haruku and Other Moluccan Islands; Part 1 \& 2 : Final Report. DEINSEA: jaarbericht van het Natuurmuseum Rotterdam : annual of the Natural History Museum Rotterdam 3(1): $1-120$.

Heij, C. J. \& Rompas, C. F. E. 1999. Ekologi Megapoda Maluku (Burung Momoa, Eulipoa wallacei) [Ecology of Maluku Megapode (Momoa Bird, Eulipoa wallacei) in Haruku Island and some of Islands in Maluku, Indonesia]. - Di Pulau Haruku Dan Beberapa Pulau Di Maluku, Indonesia (in Indonesian)

Ives, A. R. \& Carpenter, S. R. 2007. Stability and diversity of ecosystems. - Science 317(5834): 58-62. DOI: $10.1126 /$ science. 1133258

Lertzman, D. A. \& Vredenburg, H. 2005. Indigenous peoples, resource extraction and sustainable development: An ethical approach. - Journal of Business Ethics 56(3): 239-254. DOI: 10.1007/s10551-004-3528-8

Libralato, S., Christensen, V. \& Pauly, D. 2006. A method for identifying keystone species in food web models. Ecological Modelling 195(3-4): 153-171. DOI: 10.1016/j.ecolmodel.2005.11.029

Lillesand, T. M., Kiefer, R. W. \& Chipman, J. W. 2004. Remote Sensing and Image Interpretation, $7^{\text {th }}$ ed. - Wiley

Mauro, F. \& Hardison, P. D. 2000. Traditional knowledge of indigenous and local communities: International debate and policy initiatives. - Ecological Applications 10(5): 1263-1269. DOI: 10.1890/1051-0761(2000) 010[1263:TKOIAL]2.0.CO;2

Mills, L. S., Soulé, M. E. \& Doak, D. F. 1993. The keystone-species concept in ecology and conservation. BioScience 43(4): 219-224. DOI: 10.2307/1312122

Morrison, M. L., Marcot, B. G. \& Mannan, R. W. 1999. NCASI Technical Bulletin Wildlife-Habitat Relationships: Concepts and Applications. - Island Press

Nilsson, C. \& Grelsson, G. 1995. The fragility of ecosystems: A review. - Journal of Applied Ecology 32(4): 677692. DOI: $10.2307 / 2404808$

Pietersz, J. J. 2010. Fungsi Dan Peran Lembaga Kewang Dalam Perlindungan Lingkungan Di Maluku [Functions and Roles of Kewang Institutions in Environmental Protection in Maluku]. - Jurnal Konstitusi 2(1): 1-22. (in Indonesian with English Summary)

Randall, A. 1981. Resource Economics: An Economic Approach to Natural-Resource and Environmental Policy. - United States: Grid Publishing, Inc.,Columbus, OH. https://www.osti.gov/servlets/purl/7092645.

Randall, A. 2007. Benefit Cost Analysis and a Safe Minimum Standard of Conservation. - Handbook of Sustainable Development, pp. 91-105.

Ripley, S. D. 1960. Distribution and niche differentiation in species of Megapodes in the Moluccas and Western Papuan Area. - Acta XII. Congressus Internationalis Ornithologici I: 631-40.

Roberge, J. M. \& Angelstam, P. 2004. Usefulness of the umbrella species concept as a conservation tool. Conservation Biology 18(1): 76-85. DOI: 10.1111/j.1523-1739.2004.00450.x

Rugebregt, R. V. 2013. Revitalization of the Kewang Institute in the Sustainable Management of Marine and Coastal Natural Resources in Maluku Province. - In: Regulating Disasters, Climate Change and Environmental Harm: Lessons from the Indonesian Experience, pp. 438-460. DOI: 10.4337/9781781002490.00027

Saiya, H. G. 2013. Natural and artificial egg hatching of the Moluccan Scrubfowl, Eulipoa wallacei.- ResearchGate

Saiya, H. G. \& Heij, C. J. 2017. Kearifan Lokal Masyarakat Adat Di Maluku Untuk Konservasi Burung Gosong Maluku (Eulipoa wallacei) [Local Wisdom of Indigenous Peoples in Maluku for Conservation of Moluccan Scrubfowl (Eulipoa wallacei)]. - Prosiding Seminar Nasional \& CFP I IDRI (October): 17-25. (in Indonesian)

Saiya, H. G, Verboom, W. C. \& Heij, C. J. 2016. Vocal communication between Molucan Megapodes (Eulipoa wallacei). - JunoBioacoustics, Dorpsstraat 1A, 1731 RA Winkel, The Netherlands (201604): 1-19. DOI: 10.13140/RG.2.2.29502.00323

Salim, E. 1982. Conservation and development. - Environmentalist 2(2): 109-116. DOI: 10.1016/S02511088(82)92559-1 
Shogren, J. F. 1998. Private Property and the Endangered Species Act: Saving Habitats, Protecting Homes. University of Texas Press

Smith, J. A., Suraci, J. P., Clinchy, M., Crawford, A., Roberts, D., Zanette, L. Y. \& Wilmers, C. C. 2017. Fear of the human 'super predator' reduces feeding time in large carnivores. - Proceedings of the Royal Society B: Biological Sciences 284(1857): 20170433. DOI: 10.1098/rspb.2017.0433

Suter, W., Graf, R. F. \& Hess, R. 2002. Capercaillie (Tetrao urogallus) and avian biodiversity: Testing the umbrella-species concept. - Conservation Biology 16(3): 778-788. DOI: 10.1046/j.1523-1739.2002.01129.x

Toxopeus, L. J. 1922. Eenige Ornithologische Mededeelingen over Boeroe [Some Ornithological Reports on Buru]. - In Nederlansch-Indisch Natuurwetenschappelijk Congres, Bandoeng (in Dutch)

Valentijn, F. 1726. Oud En Nieuw Ost-Indiën. Derde Deel (Geschiedenissen En Zaaken van Amboina, Banda, Enz.) [Old And New East Indies. Part Three (Histories And Cases of Amboina, Banda, Etc.)]. - Verhandeling Der Vogeln van Amboina. Amsterdam/Dordrecht (in Dutch)

Verboom, W., Saiya, H. G. \& Heij, C. J. 2017. A specific call of the Moluccan Megapode (Eulipoa wallacei). JunoBioacoustics (201705): 1-6. DOI: 10.13140/RG.2.2.10627.63524

Vitousek, P. M., Mooney, H. A., Lubchenco, J. \& Melillo, J. M. 1997. Human domination of Earth's ecosystems. - Science 277(5325): 494-499. DOI: 10.1126/science.277.5325.494

Wallace, A. R. 2016. List of Birds Collected in the Island of Bouru (One of the Moluccas), with Descriptions of the New Species. - Read Books Ltd.

Walpole, M. J. \& Leader-Williams, N. 2002. Tourism and flagship species in conservation. - Biodiversity and Conservation 11(3): 543-547. DOI: 10.1023/A:1014864708777

White, C. M. 1998. Review: A guide to the birds of Wallacea: Sulawesi, The Moluccas and Lesser Sunda Islands, Indonesia by Coates, B., Bishop, K. \& Gardner, D. - The Auk 115(3): 811-813. DOI: 10.2307/4089438

Williams, G. C. 2008. Adaptation and Natural Selection: A Critique of Some Current Evolutionary Thought (Vol. 75). - Princeton University Press

Wright, D. H. 1990. Human impacts on energy flow through natural ecosystems, and implications for species endangerment. - AMBIO 19(4): 189-194. http://www.jstor.org/stable/4313691.

Xiuping, H. H. M., Kissya, E. \& Yanes, 2010. Indigenous Knowledge and Customary Law in Natural Resource Management: Experiences in Yunnan, China and Haruku, Indonesia. - Asia Indigenous Peoples Pact (AIPP) Foundation http://www.iwgia.org/iwgia_files_publications_files/0666_Indigenous_Knoledge_and_ Customary_La_in_Natural_Resource_Management.pdf.

Zerner, C. 1994. Through a green lens: The construction of customary environmental law and community in Indonesia's Maluku Islands. - Law \& Society Review 28(5): 1079-1122. DOI: 10.2307/3054024

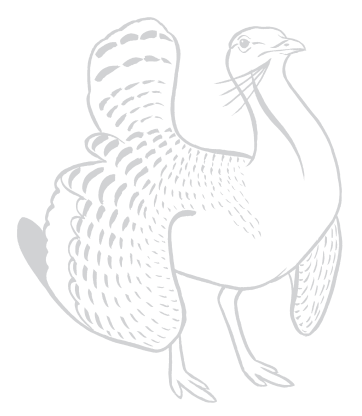

